Вікторія СИЗОНЕНКО, orcid.org/0000-0001-5414-5326 кандидат педагогічних наук, викладач кафедри хореографії та художньої культури факультету мистецтв Уманського державного педагогічного університету імені Павла Тичини (Умань, Черкаська область, Україна) nika_dance27@ukr.net

\title{
ПІДГОТОВКА МАЙБУТНЬОГО ВЧИТЕЛЯ ХОРЕОГРАФІЇ ДО ВИХОВАННЯ ВПЕВНЕНОСТІ ТА НАПОЛЕГЛИВОСТІ ЗАСОБАМИ СУЧАСНОГО БАЛЬНОГО ТАНЦЮ
}

У статті професійні переконання розглядаються як важливий складник особистості майбутнього балетмейстера. Завдання формування професійних переконань вимагають значних змін у змісті педагогічної освіти, яка у всіх ї̈ аспектах (теоретичному, практичному, психологічному) повинна забезпечувати розуміння сутності певного педагогічного явища; сприяти розумінню істини знань, посилювати роль теоретичних узагальнень, фундаментальних ідей та концепцій. Розглянуто вплив естетичного виховання на всебічний гармонійний розвиток майбутнього фахівия з хореографічного мистецттва, застосування ситуачій успіху як методу виховання особистісних якостей студента-хореографа.

Вважалося, щь ефективність формування навичок майстра балету в системі підготовки майбутнього вчителя хореографії здебільшого залежсить від створених умов. Створення мотивації майбутнього хореографа до діяльності майстра балету важливе для ефективного формування його навичок. Маючи мотивоване бажання оволодіти професією балетмейстера, він виявляє наполегливість, иілеспрямованість, ініціативність, інтелектуальну гнучкість, отримуючи при изьому певне задоволення від результатів навчання.

Основним завданням вчителя хореографії є розкриття індивідуальності кожного зі своӥх учнів. Балетмейстер зобов 'язаний виховувати не лише власні копії, а й творчо незалежних майстрів балету із власним мисленням і стилем. Він повинен виховувати студентів-однодумиів, високоосвічених фахівців і майстрів своєї справи. P. Захаров писав: "Ніщо не росте на порожньому місиі і ніколи не виникає з нічого». Досліджено, шьо рівень професійної компетентності майбутнього вчителя хореографії здебільшого залежить від того, наскільки формується його творчий потенціал.

Ключові слова: бальний танець, вчитель хореографії, танцңювальні форми, професійне становлення майбутнього вчителя, балетмейстер, педагогічні переконання, майбутній педагог.

Viktoria SYZONENKO, orcid.org/0000-0001-5414-5326 Candidate of Pedagogical Sciences, Lecturer at the Department of Choreography and Art Culture of the Faculty of Arts

Pavlo Tychyna Uman State Pedagogical University (Uman, Cherkasy region,Ukraine)nika_dance27@ukr.net

\section{PREPARATION OF THE FUTURE TEACHER OF CHOREOGRAPHY FOR EDUCATION OF CONFIDENCE AND PERSISTENCE BY MEANS OF MODERN BALLET DANCE}

The article considers the professional beliefs as an important component of the personality of a future choreographer. Tasks of forming professional beliefs require significant changes in the content of pedagogical education, which in all its aspects (theoretical, practical, psychological) should provide the insight into the essence of a particular pedagogical phenomenon; promote understanding of the truth of knowledge, strengthen the role of theoretical generalizations, fundamental ideas and concepts. The influence of aesthetic education on the comprehensive harmonious development of the future specialist in choreographic art, application of situations of success as a method of education of personal qualities of a student-choreographer is considered. It was considered that the effectiveness of the formation of ballet master's skills in the system of training the future choreography teacher depends largely on the created conditions.

Creating the motivation of the future choreographer for the ballet master's activity is also important for the effective formation of ballet master's skills. Having a strong motivated desire to master the profession of choreographer, he shows perseverance, purposefulness, initiativity, intellectual flexibility, while getting some satisfaction with the results of 
training. Only a person who has natural abilities, vocations to this kind of activity, as well as professional education can teach the art of dance and ballet performance. A teacher who has considerable experience in ballet and staging is entitled to teach this discipline.

Only those who have acquired this experience, who has something to say to their students, who has the opportunity to build classes on specific examples of ballet and staging work can share their experience with the students. The main task of the choreography teacher is to reveal the individuality of each of his or her students. The choreographer is obliged to educate not just his or her own copies, but also a pool of creatively independent ballet masters with their own thinking and style. In addition, he or she must educate like-minded students, highly educated professionals, and masters of his work. R. Zaharov wrote: "Nothing grows on an empty place, and never arise from nothing". It has been researched that the level of professional competence of the future choreography teacher depends largely on the extent to which his or her creative potential is formed.

Key words: ballroom dance, teacher of choreography, dance forms, professional formation of future teacher, ballet master, pedagogical beliefs, future teacher.

Постановка проблеми. Прагнення до танцю закладено в людині самою природою, потрібно тільки виявити це почуття. Внутрішній світ людини створює образ, образ-уявлення, раціональні елементи якого ззовні спостерігають у вигляді рухів, а емоційні сторони складають основу танцювального мистецтва як відкритого світові душевного переживання, сумісність музичного твору і фізичної краси рухів тіла танцюриста.

Бальні танці $\epsilon$ однією 3 найбільш масових і загальнодоступних форм спілкування дітей і молоді 3 основами танцювальної хореографії. Бальний танець - один із видів хореографічного мистецтва, він єдієвим засобом музичного-пластичного, художньо-естетичного, спортивно-фізичного, емоційного, тобто різностороннього розвитку й виховання особистості. Рівень розвитку сучасного бального танцювального мистецтва потребує якісної підготовки висококваліфікованих педагогів, які досконало володіють навчальним матеріалом, мають достатній рівень навчально-методичної підготовки.

Аналіз досліджень. Проблеми професійного становлення майбутнього вчителя, формування його соціальної активності та вдосконалення фахової підготовки широко висвітлені в психолого-педагогічних дослідженнях з методології та теорії формування особистості вчителя (А. Бойко, Л. Буєва, В. Сластьонін та інші), професійної підготовки фахівців (О. Абдуліна, І. Бех, І. Зязюн, Г. Падалка, О. Рудницька, О. Щолокова та інші), професійно-педагогічної діяльності (Д. Авербах, Ф. Гоноболін, П. Шавір, М. Хмель та інші). Науково-методичні видання з бальної хореографі останньої чверті XX - початку XXI ст. представлені роботами Л. Браїловської, П. Буттомера, Є. Деніцема, Д. Срмакова, О. Іванікової, А. Муром, Г. Регаццоні, А. Росі, А. Маджоні.

Мета статті полягає у комплексному та всебічному розкритті питання стосовно підготовки майбутнього вчителя хореографії до виховання впевненості та наполегливості засобами сучасного бального танцю.
Виклад основного матеріалу. На усіх етапах історичного розвитку людини підкреслювалося важливість наполегливості для характеристики поведінки індивіда. Українцям наполегливість була притаманна 3 давніх-давен, вона розглядалася як частина їхньої духовності.

Наполегливість - це одна 3 основних якостей, обов'язковий компонент у систематизації знань про волю і мораль людини. Для того, щоб дати детальну характеристику сутності поняття «наполегливість», його змісту і структурі, необхідно хоча б побіжно зупинитися на характеристиці поняття «воля», оскільки, незважаючи на те, що за останні чверть століття захищено кілька докторських дисертацій із проблем волі, довільної і вольової регуляції поведінки й діяльності людини, проблема все ще далека від вирішення. Для нашого дослідження розгляд цього питання має принципове і основне значення.

Нині погляди психологів розходяться навіть стосовно вузлових питаннь, пов'язаних із вказаною темою. Одні з них заперечують наявність волі як самостійного психологічного явища, ставлять під сумнів цінність поняття «воля», інші ж, відстоюючи самостійність волі, виокремлюють тільки одну іï сторону - здатність долати труднощі і перепони. Часто довільна регуляція виявляється відірваною від волі. У своєму дослідженні ми спираємося на думку $Є$. Ільїна і будемо розглядати проблему волі як свідоме і цілеспрямоване управління людиною власною поведінкою, діяльністю, емоціями, оскільки питання про сутність волі тісно пов'язане з проблемою мотивації, поясненням причин і механізмів активності людини (Ільїн, 2002: 6).

Виховання наполегливості розпочинається 3 раннього дитинства. У цей час дитина ще багато чого не вміє, їй ще чимало чого не вдається, у неї легко виникає незадоволеність тим, що вона робить. Незадоволеність спонукає дитину припинити розпочате, а це швидко стає звичкою не досягати мети, якщо з'явилися перешкоди. Діти 
завзято беруться за багато справ, проте їх горіння вистачає ненадовго. Вихователь уважно слідкує за цією особливістю їх поведінки і спонукає дітей, де це потрібно, доводити розпочате до кінця, допомагаючи порадою, вказівками, діючи похвалою, заохоченням, а інколи і засудженням.

У шкільному віці важлива роль у вихованні наполегливості належить колективу учнів. Колектив засуджує вияви недостатньої наполегливості і стимулює подолання труднощів. Дуже важливо, щоб педагог був наполегливим у своїй поведінці й у власних вимогах до учнів. Велике значення для студентської молоді має розвиток самостійності, вміння досягати бажаної мети. Найкращим вихователем наполегливості $€$ виробнича праця в колективі, спільне виготовлення певних цінностей на основі розподілу праці. При цьому підвищується почуття відповідальності і обов'язку перед колективом, що $є$ потужним стимулом для розвитку наполегливості, ставить роботу кожного під неперервний контроль колективу, створює сприятливі умови для об'єктивної оцінки досягнутого і тих труднощів, які були подолані (Педагогічний словник, 1960: 735).

Впевненість у собі є необхідною умовою існування особистості як суб' єкта активності, здатного до самостійного вибору цілей. Самоорганізація особистості на суб'єктивному рівні не можлива без відчуття впевненості в собі, повноцінного оволодіння собою, своєю сутністю, здатності самостійно ставити цілі і діяти відповідно до них, зберігаючи адекватну критичну позицію стосовно самого себе, здатності передбачати результати дій до їх виконання, самостійно будувати стратегію досягнення цілей відповідно до внутрішніх особистісних змістів. Це означає вміння співвідносити потреби, які виникають, із власними можливостями та $з$ прийнятними для цієї людини способами реалізації, що відповідає соціокультурним орієнтирам певного суспільства в кожній конкретній ситуації (Харламенкова, 1999: 35).

Впевненість у собі - це одна із найнеобхідніших якостей у сучасному світі. Без неї людина - як машина без пального. Відчуття власної вартості як трамплін, з якого ми стрибаємо, щоб досягти своєї мети. Це спосіб, у який ми думаємо про себе, як себе відчуваємо. Воно формується в ранньому дитинстві. На усвідомлення власної вартості (впевненості в собі) впливає багато чинників. На більшість із них батьки мають великий вплив, хоча часто цього не усвідомлюють. Потім вони дивуються, що дитина несмілива, не може пережити поразки і постійно повторює, що їй нічого не вдається, вона цьому ніколи не навчиться.
Великий енергетичний потенціал у формуванні впевненості особистості має наполегливість, віра у власний успіх, які $є$ «своєрідним духовним випередженням перетворення можливості на дійсність» (Нестеренко, 1995: 87). Від того, наскільки людина впевнена в успіху, залежить іiі наполегливість у певній діяльності, мотивація. Чим більше людина сподівається на успіх і наполеглива в діях, чим більше зусиль вона здатна докласти, тим сильнішою буде ії мотивація.

Хореографічне мистецтво загалом і бальний танець зокрема $\epsilon$ засобами розвитку і виховання внутрішньої цілісності людини. Хореографічна діяльність $є$ одним із видів художньо-творчої діяльності, яка в специфічній, властивій тільки їй формі-танцях відображаєвнутрішнійсвітлюдини, ii бажання, прагнення, творче становлення, через правильно організовану навчально-виховну діяльність у хореографічному колективі сприяє формуванню морально-вольових якостей вихованців. Почуття колективу, сумлінне ставлення до праці, стійкість, воля, дисципліна, готовність до подолання труднощів, наполегливість, впевненість у собі - всі ці якості можуть виховуватися в учнів у процесі занять хореографічним мистецтвом.

Бальне хореографічне мистецтво відіграє важливу роль у формуванні естетичного ставлення до навколишнього світу та у вихованні таких особистісних якостей як творча активність, наполегливість, ініціативність, впевненість у собі (Сизоненко, 2014: 152). Бальна хореографія була і залишається об'єктом наукових інтересів сучасних дослідників. Нині завдяки наполегливій праці мистецтвознавців і педагогів здійснюється поступовий комплексний аналіз напрямів сценічної та конкурсної бальної хореографії. Без урахування особливостей розвитку цього напряму не можливо досягти об' єктивних наукових результатів.

Бальний танець - явище багатопланове і динамічне, у сфері якого постійно відбувається пошук нових стилів і форм. Необхідність дослідження жанрово-стилістичних процесів розвитку бальної хореографії зумовлена синтетичними процесами в культурі, які завжди характеризуються відчутнішим взаємопроникненням різних видів мистецтв, поєднанням елементів культури, дозвілля і спорту, що призводить до утворення не лише нових якостей хореографічного твору, але й удосконалює вже сформовані мистецькі форми (Павлюк, 2013: 96).

Термін бальні танці походить від слова «бал», що в перекладі з латинського "ballare" означає «танцювати». Історія розвитку бальних танців тісно пов'язана 3 історією нашого суспільства. Зміни, які відбувалися в економічній, соціаль- 
ній, політичній сфері життя, рівень загальної культури суспільства знаходять своє відображення в художній творчості народу й у бальній хореографії. До створення та розвитку бальних танців долучило свою фантазію і талант не одне покоління талановитих хореографів, музикантів, виконавців і педагогів. Бальний танець як один із видів хореографічного мистецтва є специфічною формою відображення історичної дійсності. Як історичне явище своїм корінням він сягає в побутові форми народного танцю.

Останні десятиліття характеризуються появою танців підвищеної ритмічності. Часто їх так і називають - «ритмічні танці». Своєю спортивністю, близькістю до рухливого сучасного способу життя вони захоплюють все більше молоді. Сучасний рівень розвитку сучасного бального танцювального мистецтва потребує якісної підготовки висококваліфікованих педагогів, які досконало володіють навчальним матеріалом, мають достатній рівень навчально-методичної підготовки. Орієнтація педагогічного процесу на розвиток особистості учня потребує переосмислення мети та завдань фахової підготовки майбутніх вчителів хореографії, здатних до творчої самореалізації в професійній діяльності, втілення в практику як традиційних, так і інноваційних форм і методів навчання (Забредовський, 2008: 39).

Ефективність формування балетмейстерських умінь у системі підготовки майбутнього вчителя хореографії здебільшого залежить від створених умов. Важливе значення для ефективного формування балетмейстерських умінь має створення в майбутнього вчителя хореографії мотивації до балетмейстерської діяльності. Маючи стійке мотивоване бажання оволодіти професією хореографа, він виявляє наполегливість, цілеспрямованість, ініціативність, інтелектуальну гнучкість, отримуючи при цьому певне задоволення від результатів навчання.

I. Кощавець стверджує, що для стимулювання світоглядної мотивації майбутніх вчителів хореографії необхідно оволодіти системою дидактичних методів і прийомів, які мають на меті забезпечення привабливого характеру самореалізації в мистецько-педагогічній діяльності та спілкуванні. Насамперед це формування позитивного ставлення до виступів перед публікою, потреби у виконавській діяльності, психологічної готовності й задоволення від неї, потреби в мистецькій взаємодії та спілкуванні (Кощавець, 2014: 171).

Ще однією умовою формування балетмейстерських умінь $\epsilon$ виконавська підготовка балетмейстера. Насамперед вона є творчим процесом, який полягає в індивідуальній інтерпретації хореографічного матеріалу, що відображає особистісні та індивідуально-художні особливості балетмейстера «Я - виконавець». Індивідуальність у виконавській підготовці майбутнього балетмейстера забезпечує самоактуалізацію, яка є складним процесом у виборі власного індивідуального стилю.

На думку Л. Андрощук, індивідуальний стиль це модель діяльності, яка базується на сукупності різнорівневих властивостей людини і забезпечує iii активне становлення у суспільстві на засадах самоактуалізації, творчої самореалізації, суспільної діяльності в межах особистісного креативного вибору (Андрощук, 2005: 8).

Щоб виконувати професійні функції, вчитель хореографії згідно з кваліфікаційними характеристиками повинен знати:

- загальнотеоретичні дисципліни в обсязі, необхідному для успішного виконання психологопедагогічних та управлінських завдань, засвоєння методологічних і прикладних питань свого фаху;

- системи освіти і виховання дітей, основні напрями і перспективи розвитку освіти та педагогічної науки в Україні та світі;

- методи організації спілкування педагога 3 дитиною;

- форми і типи культур, основні культурноісторичні центри та регіони світу, історію культури України, ії місце в системі світової культури та цивілізації (Виготський, 1991: 225);

- історію хореографічного мистецтва, українську народну хореографічну творчість;

- види хореографічного мистецтва, стильові особливості та специфіку виконання танців різних епох, народів;

- теоретичні основи класичного, народно-сценічного, українського народного, історико-побутового, сучасного бального танців, мистецтва балетмейстера;

- методику хореографічної освіти дітей, організації та роботи 3 дитячими хореографічними колективами.

На цих знаннях грунтуються педагогічні переконання майбутніх вчителів-хореографів, які істотно впливають на напрям мислення і дій, зумовлюючи лінію поведінки, загальний стиль роботи, формуючи відповідні установки, визначаючи суб' єктивну готовність особистості до педагогічної діяльності. Проблема полягає в тому, щоб за роки навчання у педагогічному виші сформувати ці переконання у студентів-хореографів, розвинути в них усвідомлення провідної мети хореографічної освітньої діяльності, бажання працювати в обраній сфері, виробити особистий творчий стиль діяльності. 
Класифікація індивідуальних стилів діяльності хореографа включає такі компоненти: емоційнотворчий, творчо-індивідуальний, творчо-інтелектуальний, творчо-імпровізаційний стилі (Андрощук, 2005: 7). Розподіл стилів є узагальненим і умовним, оскільки творча індивідуальність здебільшого виражається не в спільних, а у відмінних рисах індивідуального стилю виконавської підготовки балетмейстера.

Майбутній вчитель бальних танців повинен оволодіти вмінням поєднувати різні методи навчання, оскільки бальне танцювальне мистецтво це ще й спорт, адже бальні танці офіційно визнані одним із видів спорту. Поряд зі спортивним аспектом бальні танці мають і соціальне значення, оскільки їх танцюють для задоволення й розваги та використовують у сценічному мистецтві: в кіно, театрі, різних концертах і шоу на телебаченні (Сизоненко, 2017: 57).

Відомий дослідник цієї проблеми А. Бєлкін зазначає, що необхідно використовувати на заняттях такі прийоми створення ситуацій успіху: «даю шанс», «сповідь», «прямуй за нами», «емоційний сплеск», «обмін ролями», «зараження», «еврика», «навмисна помилка», «лінія горизонту». Тому важко говорити про якісь прийоми створення ситуацій успіху, але існують певні закономірності, які можна розробити у своєрідний алгоритм педагогічних дій (Белкін, 1991: 89).

Майбутній вчитель має досягти достатнього рівня хореографічної та педагогічної культури, щоб бути здатним на гуманістичних засадах давати хореографічну освіту дітям. Не менш важливою умовою формування творчого потенціалу майбутнього вчителя хореографії засобами танцювального мистецтва є свобода. Свобода в педагогічному процесі - це співтворчість педагога та студента у вирішенні нових освітніх і виховних завдань (Лихвар, 2003: 13).

Мистецтво танцю - внутрішня творча свобода особистості танцівника, спрямована на вияв бажаного результату через рух, пози, художній образ, емоції. Тому важливим завданням педагога-хореографа $\epsilon$ забезпечення раціонального співвідношення свободи та необхідності в навчальновиховному процесі студента-хореографа. При цьому свобода не ототожнюється із вседозволеністю. Вона означає можливість іти власним шляхом, наскільки дозволяють конкретні обставини навчального процесу. Завдання формування педагогічних переконань передбачають внесення до навчально-виховного процесу суттєвих змін, пов'язаних із визначенням такого змісту професійної підготовки, який в усіх своїх аспектах (теоретичному, практичному, психологічному) забезпечуватиме проникнення в сутність певного педагогічного явища, сприятиме осягненню істинності знань, посиленню ролі теоретичних узагальнень, фундаментальних ідей та понять, які відображають методологію мистецької освіти.

Свобода нерозривно пов'язана 3 відповідальністю особистості за власний вибір. Вона може виражатися у виборі цілей діяльності, засобів досягнення мети. На нашу думку, свобода в бальній хореографії важлива, оскільки спортивний аспект часто не дає можливості вийти за межі конкурсних вимог. Тому саме майбутні фахівці 3 хореографії на сучасному етапі розвитку бальних танців мають навчитися впроваджувати інноваційні педагогічні методи для багатогранного розвитку майбутнього покоління. Доведено, що по-справжньому високого творчого рівня викладання може досягти лише той учитель, який має стійкі педагогічні переконання, володіє розвинутим діалектичним стилем мислення, здатний до об'єктивного й різнобічного осмислення хореографічно-педагогічної дійсності, до іiі самостійної, критичної оцінки і творчого перетворення (Шевченко, 2006: 55).

Висновки. Отже, на шляху становлення висококваліфікованого фахівця 3 хореографії кожен майбутній педагог повинен знати, як застосовувати набуті знання на практиці, поєднувати різні педагогічні методи та підходи, створювати сприятливі умови для вивчення сучасного бального танцювального мистецтва. Рівень професіоналізму майбутнього вчителя хореографії здебільшого залежить від того, наскільки сформований його творчий потенціал.

Бальний танець має достатній набір методів і прийомів для майбутнього педагога-хореографа. Сучасне бальне танцювальне мистецтво - ефективний засіб процесу формування творчого потенціалу майбутнього вчителя хореографії. Головний шлях формування педагогічних переконань полягає у збагаченні студентів-хореографів знаннями й уміннями, важливими для їх інтелектуально-емоційного ставлення до цих знань як до істинних; виробленні стійких педагогічних поглядів, впевненості у правильності своїх думок і дій; вихованні професійних потреб, які спонукають до діяльності відповідно до власних ціннісних орієнтацій; досягненні органічної єдності знань, переконань і практичної дії. 


\section{СПИСОК ВИКОРИСТАНИХ ДЖЕРЕЛ}

1. Андрощук Л. М. Індивідуальний стиль діяльності як засіб вираження творчої особистості педагога-хореографа. Науковий часопис Національного педагогічного університету імені М. П. Драгоманова. Серія 16. Творча особистість учителя: проблеми теорії і практики : збірник наукових праць. Вип. 4. К. : НПУ, 2005. С. 6-10.

2. Белкин А. С. Ситуация успеха. Как её создать? М. : Просвещение, 1991. 156 с.

3. Выготский Л. С. Педагогическая психология. Москва : Педагогика, 1991. 480 с.

4. Забредовський С. Г. Сучасні аспекти хореографічної діяльності : методичні рекомендації для студентів хореографічних спеціалізацій і керівників хореографічних колективів. К. : ДАКККіМ, 2008. 39 с.

5. Ильин Е. П. Психология воли. СПб : Питер, 2002. 288 с.

6. Кощавець I. М. Формування творчого потенціалу майбутнього вчителя хореографії засобами народно-сценічного танцю. Педагогіка формування творчоїособистості у вищій і загальноосвітній школах. 2014. Вип. 38. С. $171-178$.

7. Лихвар В. Д. Розвиток художньо-творчого потенціалу молодших школярів у процесі образотворчої діяльності : автореф. дис. канд. пед. наук: 13.00.07. Херсон, 2003. 22 с.

8. Нестеренко В. Г. Вступ до філософії: антологія людини : навч. посібн. для студ. ВНЗ. К. : Абрис, 1995.336 с.

9. Павлюк Т. С. Жанрово-стильова еволюція бального танцю ХХ століття. Украӥнська культура: минуле, сучасне, иляхи розвитку. 2013. С. 95-101.

10. Педагогический словарь: в 2 т. М. : АПН, 1960. Т. 1.775 с.

11. Сизоненко В. А. Виховання наполегливості та впевненості в молодших школярів засобами хореографічного мистецтва. Дисертація канд. пед. наук: 13.00.07, Уман. держ. пед. ун-т ім. Павла Тичини. Умань, 2014.200 с.

12. Сизоненко В. А. Формування творчого потенціалу майбутнього вчителя хореографії засобами бального танцювального мистецтва. Актуальні питання мистецької освіти та виховання : науковий журнал. Вип. 2 (10) / гол. ред. Ніколаї Г. Ю. Суми : ФОП Цьома С. П., 2017. С. 57-64.

13. Харламенкова Н. Е. Стратегии самоутверждения и ценностные предпочтения одинокого человека. Психологический журнал. 1999. № 2. С. 33-39.

14. Шевченко В. Т. Мистецтво балетмейстера в народно-сценічній хореографії : навчально-методичний посібник для вищих навчальних закладів культури і мистецтва України. К. : ДАКККіМ, 2006. 184 с.

\section{REFERENCES}

1. Androshchuk L. M. Indyvidualnyi styl diialnosti yak zasib vyrazhennia tvorchoi osobystosti pedahoha-khoreohrafa. [Individual style of activity as a means of expressing the creative personality of a teacher-choreographer]. Scientific journal of the National Pedagogical University named after M. P. Drahomanova, 2005, № 4, p. 6-10 [in Ukrainian].

2. Belkyn A. S. Sytuatsyia uspekha. Kak eë sozdat? [Success situation. How to create it?]. Moscow, Prosveshchenye, 1991, 156 p. [in Russian].

3. Vyhotskyi L. S. Pedahohycheskaia psykholohyia. [Pedagogical psychology]. Moscow : Pedagogika, 1991, 480 p. [in Russian].

4. Zabredovskyi S. H. Suchasni aspekty khoreohrafichnoi diialnosti : metodychni rekomendatsii dlia studentiv khoreohrafichnykh spetsializatsii ta kerivnykiv khoreohrafichnykh kolektyviv. [Modern aspects of choreographic activity : methodical recommendations for students of choreographic specializations and leaders of choreographic groups]. Kyiv : DAKKKiM, 2008, 29 p. [in Ukrainian].

5. Ylyn E. P. Psykholohyia voly. [The psychology of will]. St. Petersburg, 2002, 288 p. [in Russian].

6. Koshchavets I. M. Formuvannia tvorchoho potentsialu maibutnoho vchytelia khoreohrafii zasobamy narodno-stsenichnoho tantsiu. [Formation of creative potential of the future teacher of choreography by means of folk-stage dance]. Pedagogy of formation of creative personality in higher and general education schools. 2014, № 38, p. 171-178 [in Ukrainian].

7. Lykhvar V. D. Rozvytok khudozhno-tvorchoho potentsialu molodshykh shkoliariv u protsesi obrazotvorchoi diialnosti. [Development of artistic and creative potential of junior schoolchildren in the process of artistic activity]. Extended abstract of candidate's thesis. Kherson, 2003, 22 p. [in Ukrainian].

8. Nesterenko V. H. Vstup do filosofii: antolohiia liudyny. [Introduction to philosophy: an anthology of man]. Kyiv, 1995, 336 p. [in Ukrainian].

9. Pavliuk T. S. Zhanrovo-stylova evoliutsiia balnoho tantsiu XX stolittia. [Genre and style evolution of ballroom dancing of the XX century]. Ukrainian culture: past, present, ways of development, 2013, p. 95-101 [in Ukrainian].

10. Pedahohycheskyi slovar. [Pedagogical dictionary]. Moscow, 1960, Vol. 4, 556 p. [in Russian].

11. Syzonenko V. A. Vykhovannia napolehlyvosti ta vpevnenosti v molodshykh shkoliariv zasobamy khoreohrafichnoho mystetstva. [Education of persistence and confidence in junior schoolchildren by means of choreographic art]. Candidate's thesis. Uman, 2014, 200 p. [in Ukrainian].

12. Syzonenko V. A. Formuvannia tvorchoho potentsialu maibutnoho vchytelia khoreohrafii zasobamy balnoho tantsiuvalnoho mystetstva. [Formation of creative potential of the future teacher of choreography by means of ballroom dance art]. Current issues of art education and upbringing: a scientific journal. Sumy, 2017, № 2(10), p. 57-64 [in Ukrainian].

13. Kharlamenkova N. E. Stratehyy samoutverzhdenyia y tsennostnыe predpochtenyia odynokoho cheloveka. [Strategies of self-affirmation and value preferences of a single person]. Psychological Journal, 1999, № 2, p. 33-39 [in Russian].

14. Shevchenko V. T. Mystetstvo baletmeistera v narodno-stsenichnii khoreohrafii. [The art of the choreographer in folkstage choreography]. Kyiv : DAKKKiM, 2006, 184 p. [in Ukrainian]. 